\title{
A PROPÓSITO DO CENTENÁRIO DE RAUL POMPÉIA
}

\author{
Otto Maria Carpeaux
}

Quem diz Raul Pompéia, diz O Ateneu. O resto só vive e só interessa porque seu autor é o mesmo desse romance, talvez o mais lido de toda a literatura brasileira, porque talvez o mais intimamente brasileiro de todos: O Ateneu significa um "momento" de sensibilidade brasileira, mas no sentido dos momentos que sempre voltam.

Vivo contraste: a bibliografia sobre Raul Pompéia e sua obra é escassa, e nos poucos estudos de valor sempre se repetem os mesmos conceitos, os mesmos chavões; desejo, porém, salientar a exceção que é Psicologia e estética de Raul Pompéia, de Maria Luísa Ramos, professora da Universidade de Minas Gerais, trabalho que não foi apreciado como merece porque feito na província - o que não é um caso isolado, mas exige reparação.

A insuficiência das pesquisas deixou aberta a questão de definir a atitude literária do autor de O Ateneu. Nos manuais didáticos e na consciência dos leitores em geral, a obra é considerada como romance naturalista. Será? Quem diz "naturalismo brasileiro", diz Zola, diz até imitação de Zola. Mas O Ateneu não é, em sentido nenhum, um romance zolaesco; um abismo o separa das obras de Aluísio Azevedo, de Adolfo Caminha; também falta nele um ingrediens especificamente brasileiro do naturalismo, a influência de Eça de Queirós. O Ateneu é fruto de uma sensibilidade totalmente diferente. Em 1949, colocado perante a tarefa difícil de caracterizar a obra, só me ocorreu o rótulo impressionismo.

Desde então, essa definição caiu, parece, no domínio público; pois em volumes publicados em 1955 e em 1959 encontrei-a repetida sem aspas. Melhor, talvez: pois os motivos da redefinição foram outros. Os autores não se referiram a impressionismo como atitude artística e só como particularidade de estilo; mas quanto à definição do estilo de Pompéia como impressionista prioridade cronológica pertence a Agripino Grieco, tampouco citado. Uma crítica que, embora pretendendo fazer a revisão dos valores de obras do passado, elimine deliberadamente os fatores históricos, está condenada a terminar num impasse.

On ne détruit ce quion remplace. Quem nega o naturalismo de O Ateneu, tem de perguntar como chegou a surgir o equívoco. O romance parecia naturalista, porque 
a sensibilidade à flor da pele de Pompéia percebeu coisas que os outros não perceberam. Descobriu território novo. Mas descobrir territórios novos é a função histórica do naturalismo.

Se O Ateneu fosse romance naturalista, teria de ser considerado como documento: sobre a mentalidade da mocidade brasileira e sobre os métodos do ensino no Brasil no fim do século xIx. Seria mero documento histórico, e não haveria muitos motivos para comemorar neste ano o centenário de seu autor. Mas este criou uma obra de arte que sobrevive: é, aliás assim, que Maria Luísa Ramos a encarou e analisou. E a literatura brasileira ficou mais rica de uma dimensão.

Chegamos a um resultado aparentemente paradoxal: é no valor artístico que reside a atualidade da obra de Pompéia. Seu romance é inimitável, porque as obras de arte não podem, não devem e não precisam ser imitadas. Mas a sensibilidade que o criou é um exemplo. Vivemos hoje num Brasil diferente: diferente não somente do Brasil de 1888, mas também do Brasil de 1922 e do Brasil de 1930 e do Brasil de 1935 e até do Brasil de ontem. É uma vida nova que espera seu romance novo, em vez da repetição de esquemas psicológicos ou regionalistas, surrealistas ou infra realistas ou de um estilo à procura de uma sensibilidade. Ao romancista brasileiro de hoje, sensível à realidade que o rodeia e que penetra nele, pode-se acenar com a possibilidade de descobrir territórios novos. Eis a lição de Pompéia.

In: Leitura, nº 70-71, RJ, abr.-mai. 1963. 